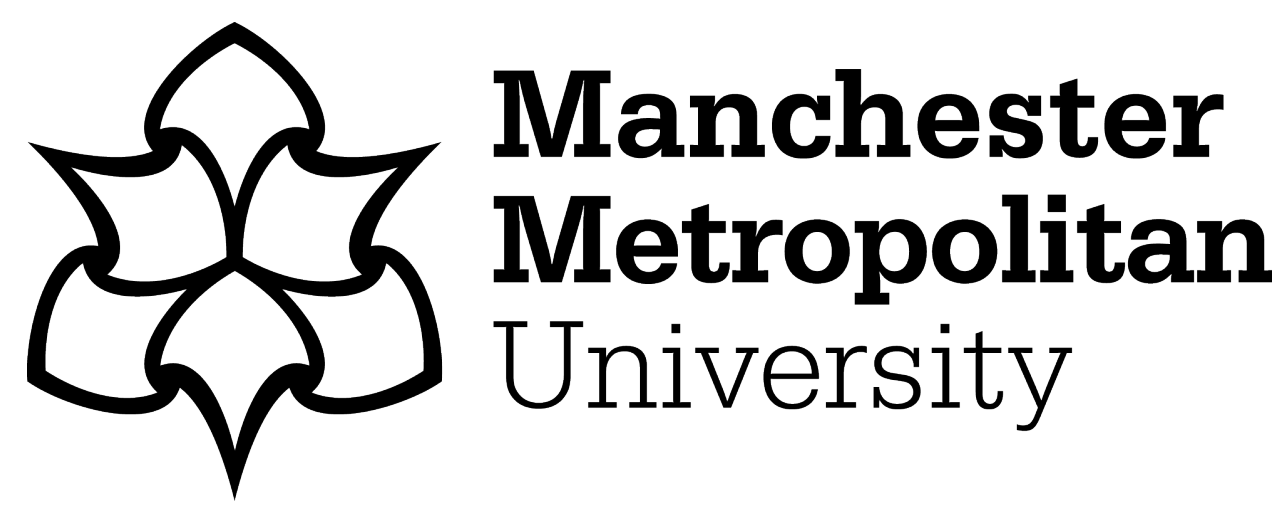

Crome, AP (2016) The Jewish Indian theory and Protestant use of Catholic thought in the early modern Atlantic. In: Puritans and Catholics in the TransAtlantic World 1600-1800. Christianities in the Trans-Atlantic World . Palgrave Macmillan, pp. 112-130. ISBN 1137368985

Downloaded from: https://e-space.mmu.ac.uk/619589/

Publisher: Palgrave Macmillan

Please cite the published version 


\section{The "Jewish Indian" Theory and Protestant use of Catholic Thought in the Early Modern Atlantic}

\section{Andrew Crome}

On encountering the preface to Thomas Thorowgood's 1650 Jewes in America, or, Probabilities that the Americans are of that race, it is tempting to accuse the writer of a narrow parochialism. "Britain", he began, "has woon [sic] the gospel glory from all other countries... it was the first of all the provinces that established Christianity by law... our Lucius was the first Christian king... our K. Henry the Eight was the first of all princes who brake that yoke of Antichrist". ${ }^{1}$ Aside from betraying its author's high view of monarchy (Charles I's execution forced Thorowgood to delay publication and choose a new dedicee), ${ }^{2}$ the passage reveals confidence in a nation blessed by God and enjoying international preeminence in the gospel. It is easy to see how Thorowgood's position could be used to support the idea of England as an elect nation; a new Israel leading the world into a (Protestant) utopia. Yet Thorowgood did not stop with Henry's breaking of Antichrist's yoke. Instead he fixed his historical lens further into the past, reminding readers of the many European supports that English faith had received. The English were not natives of their own land, instead being a collection of Jutes and Angles who emigrated from Germany. It was in this continental setting that they were educated in the faith. Following the English Catholic antiquarian Richard Verstegan, Thorowgood reminded his readers that these original immigrants, who constituted a "first England" in ancient Germany, were initially converted to Christianity through interactions with the Jewish community on the continent. Visualising a neat symbolic closure, Thorowgood suggested that if the newly discovered Native Americans

\footnotetext{
${ }^{1}$ Thomas Thorowgood, Iewes in America or, Probabilities that the Americans are of that Race (London, 1650), sig. bv.

${ }^{2}$ The original dedication was finally printed in more propitious times in Thorowgood's Jews in America... Made more probable by some additionals to the former conjectures (London, 1660). 
were the descendants of the lost Jewish tribes, then the favour would be repaid: "from this second England God hath so disposed the hearts of many in the third, New England, that they have done more in these last few yeares towards their conversion, then hath been effected by all other nations and people that have planted there since they were first known to the habitable world". 3

Thorowgood's position, rather than narrowly focusing on the English context, deployed a wide-angled lens in its examination of the map of faith. England's position was only to be understood in relation to the nation's relationship with the continent and its transatlantic possessions. Awareness of the historicity of the nation and its immigrant past combined with millennial optimism and a focus on the opportunities of the new world. Far from parochial, Thorowgood joined an interest in Catholic scholarship, continental examinations of national history, and news from America to frame a debate which touched upon a wide, Atlantic context. It is this context which is examined here. While many examinations of early modern eschatological texts, and those which focus upon the eschatological role of Native Americans in particular, have tended to concentrate on immediate political or personal reasons for their composition, ${ }^{4}$ this chapter argues that the debate should be analysed in a wider Atlantic context. In doing so, it is possible to appreciate the extent to which Catholic works could be used by Protestants in their own eschatological speculation. While the papacy could be condemned as Antichrist, at the same time both Protestants and Catholics were engaging with the same eschatological questions and making use of the same resources to do so. As Jorge Cañizares-Esguerra has argued, remarkably

\footnotetext{
${ }^{3}$ Thorowgood, Jewes, sig. b2r

${ }^{4}$ For example, Claire Jowitt, "Radical Identities? Native Americans, Jews and the English Commonwealth", Seventeenth Century 10:1 (Spring 1995) 101-119; Ronnie Perelis, “'Those Indians are Jews!': Lost Tribes, Crypto-Jews, and Jewish Self-Fashioning in Antonio de Montezinos's Relación of 1644” in Richard L. Kagan and Philip D. Morgan (eds), Atlantic Diasporas: Jews, Converso and Crypto-Jews in the Age of Mercantilism 1500-1800 (Baltimore: Johns Hopkins University Press, 2009), pp.195-199. 
similar eschatological themes emerged in the English Atlantic and Spain. ${ }^{5}$ Millennial ideas about the New World circulated throughout the Atlantic, and the "Jewish Indian" theory that Thorowgood promoted should be seen in this context as part of the shared heritage of Catholic and Protestant colonisation. Adding to this melting pot of prophetic speculation, Jewish writers were also regularly engaged with. Indeed, their evidence was considered crucial to the sorts of questions being debated by both Protestants and Catholics in the period. While eschatological theories can often appear to be limited by their national contexts or focused on the destruction of a despised "other", they were often the product of a wider Atlantic intellectual community, with Protestant, Catholic, and Jewish speculation demonstrating important commonalities.

\section{The Jewish Indian Theory}

Eschatological fascination with the Jews had a long history in England, but developed into a particularly strong form from the early seventeenth century onwards. The idea that a large number of Jews would convert to Christianity in the end times was an established belief with a provenance dating back to the early church. The primary justification for this belief could be found in Romans 9-11, in which the apostle Paul asserted that "all Israel will be saved" (Romans 11:26). The exact timing of this conversion - whether it would happen before or with the end itself- was uncertain, but it was a position that was held by both Protestants and Catholics in early modern Europe. ${ }^{6}$

\footnotetext{
${ }^{5}$ Jorge Cañizares-Esguerra, Puritan Conquistadors: Iberianizing the Atlantic, 1550-1700 (Stanford: Stanford University Press, 2006), pp.83-119.

${ }^{6}$ See Andrew Crome, The Restoration of the Jews: Early Modern Hermeneutics, Eschatology, and National Identity in the Works of Thomas Brightman (Cham: Springer, 2014), pp.29-58; David Katz, Philo-Semitism and the Readmission of the Jews to England 1603-1655 (Oxford: Clarendon, 1982) pp.90-126; Robert O. Smith, More Desired than Our Owne Salvation: The Roots of Christian Zionism (Oxford: OUP, 2013), pp.47-69. 
A belief in Jewish conversion was not necessarily related to millennialism. It was possible, as in the case of the towering puritan figure of William Perkins, to argue that speculation about the coming eschaton was pointless as the Jews had not yet been converted. ${ }^{7}$ From the early seventeenth century onwards, however, a number of writers tied Jewish conversion into an imminent coming of Christ, as well as according the Jews a much greater role than they had previously been granted in apocalyptic events. Figures such as Thomas Brightman (1562-1607), Henry Finch (1558-1625) and Joseph Mede (1586-1638) found a more focused role for the Jews. Converted Jews would prove to be the cause of the destruction of the Ottoman Empire ("the Turk") and (occasionally) papal forces as well. After this victory, the Jews would constitute a visible, separate nation in Palestine, from which they would have dominion over the nations. ${ }^{8}$ This sort of thinking had obvious appeal to writers holding a premillennial position, although this form of prophetic speculation was also espoused by those who adopted other interpretations of Revelation 20. As this type of eschatology focused on the Jews to such a great extent, it can be labelled "Judeo-centric". 9

In this chapter, I consider a particular off-shoot of Judeo-centric eschatology - that is, the idea that Native Americans were in fact the lost tribes of Israel. In doing so, I aim to situate the Judeo-centric debate within a wider Atlantic context, and to offer glimpses of the correspondence network which helped to inform eschatological speculation in England and New England in the seventeenth century. Interpretations of eschatology in the Atlantic have often been resolutely Anglophone in their context, and limited to looking at continental

\footnotetext{
${ }^{7}$ William Perkins, "A Fruitfull Dialogue...concerning the End of the World" in Works (London, 1631) Vol. III , p.470.

${ }^{8}$ See Richard W. Cogley, "The Fall of the Ottoman Empire and the Restoration of Israel in the 'Judeo-Centric' Strand of Puritan Millenarianism”, Church History 72 (2003), pp.304-322; Andrew Crome, "“The Proper and Naturall Meaning of the Prophets": The Hermeneutic Roots of Judeo-centrism in Puritan Eschatology', Renaissance Studies 24:5 (2010), 725-741.

${ }^{9}$ Cogley, “Fall”, p.304. 
Catholicism as an "other" against which Protestants reacted. To some extent this is unsurprising, given the level of vitriol seventeenth-century writers often expressed against the Roman church. But as Alec Ryrie recently pointed out in work on Protestantism in early modern England, Protestants were not averse to using Catholic texts when it suited them. $\mathrm{He}$ highlights the adoption of Catholic works for Protestant devotion, albeit often with some form of modification. ${ }^{10}$ Eschatology initially appears an unpromising arena for this sort of appropriation, given the Protestant focus on the overthrow of the papacy as the climax of the book of Revelation. ${ }^{11}$ Nonetheless, as I have noted elsewhere, Catholic (and particularly Jesuit) sources could be adapted and worked into complex Protestant prophetic schemes, while their authors maintained a standard antipapal position. ${ }^{12}$ As a sense of millenarian enthusiasm often marked early Iberian endeavours, particularly amongst the spiritual Franciscans, eschatological speculation offers a fruitful arena for examining commonalities and shared themes among Protestants and Catholics. ${ }^{13}$ Prophecy offered a number of opportunities for Protestant-Catholic interaction, and the Jewish Indian theory proved to be one of them.

What was the Jewish Indian theory? As Judeo-centric prophecy required the conversion and return of large numbers of Jews to Palestine, it became important to deal with the thorny issue of the location of the majority of the Jewish tribes. Contemporary Jews were members of the tribes of Judah and Benjamin, with the ten tribes that made up the northern kingdom of Israel (in contrast to the southern kingdom of Judah) having been exiled following the Assyrian conquest in c. 722 BCE. Their fate was a mystery. Discussions about

\footnotetext{
${ }^{10}$ Alec Ryrie, Being Protestant in Post-Reformation Britain (Oxford: OUP, 2013), pp.281-292.

${ }^{11}$ For details on the development of this tradition see Crawford Gribben, The Puritan Millennium: Literature and Theology (Milton Keynes: Paternoster, 2008), pp.21-58.

12 Crome, Restoration of the Jews, pp.115-117.

${ }^{13}$ See Cañizares-Esguerra, pp.24-26, 52-55 and Bernard Bailyn, Atlantic History: Concept and Contours (Cambridge, Mass.: Harvard University Press, 2005), pp.76-79. 
the "lost tribes of the Jews" are therefore something of misnomer - technically, the tribes were "Israelites". Nonetheless, seventeenth-century writers repeatedly refer to them as "Jews", a usage I follow here. The debate on the location of the tribes did not emerge exnihilo in the seventeenth century. As with the concept of mass Jewish conversion, the possible location of the tribes had fascinated Christian writers from the early church onwards. ${ }^{14}$ The novelty of debates in the seventeenth century lay in the particular eschatological importance that was placed on the discovery of the missing Israelites. Prophecies of the restoration of the Jews in the Old Testament were clear that the tribes of Judah and the tribes of Israel would be reunited in Palestine (e.g. Ezk. 37). As apocalyptic exegetes analysed the details of Daniel and Revelation, they realised that were the tribes to be located it would be a further sign of the approaching coming of Christ.

When discussing the current locations of the tribes, three options were generally considered. The first was based upon their last known location in Assyria. This held that the tribes were currently located somewhere in Asia, but declined to be more specific as to their current location. Based on a combination of Revelation 16, in which the Euphrates dries as the "Kings of the Earth" march across it, and the apocryphal book II Esdras, this scenario was intimately linked to the destruction of the Ottoman Empire. The second position also found the tribes still in Asia, but it located them among known people groups - in particular the supposedly barbarous Tartars. This position argued that the Jews had degenerated into the Tartars, forgetting their true identity as they awaited their recall at the end of time. Alternatively, it was possible to argue that Jews were present as a separate people group within the Tartar tribes. Giles Fletcher, Elizabeth I's ambassador to Moscow, held this view

\footnotetext{
${ }^{14}$ See Tudor Parfitt, The Lost Tribes of Israel: The History of a Myth (London: Weldenfeld \& Nicholson, 2002), pp.1-25. 6
} 
and produced a proto-anthropological study to support it. Although not published until 1677, it nonetheless circulated widely in manuscript. ${ }^{15}$ A third view was that the lost tribes had migrated to America, and were now present among the natives there: the so-called Jewish Indian theory. This opinion was neither new nor unique to the Anglophone world. It had been previously explored by writers such as Joannes Fredericus Lumnius, Peter Martyr d'Anghiera and Gilbert Genebrard ${ }^{16}$ and discussed in negative terms by José de Acosta and Gregorio Garcia in Spain. ${ }^{17}$ It is important to recognise that none of the theories in circulation were necessarily exclusive of one another - it was possible to affirm that there were Jews among the Tartars and among the Native Americans. Neither did the millennial position of a particular commentator presuppose that they supported any particular theory - the most influential premillennial commentator of the pre-civil war era, Joseph Mede, had infamously suggested that Americans might be a people who were led the continent by Satan with no chance of conversion, a position itself adapted from Franciscan Juan de Torquemada. ${ }^{18}$ What was important about the Jewish Indian theory in England was the way in which it was developed and publicised, as well as the Atlantic information network that gave it birth, something which has not always been appreciated in previous work on the subject. ${ }^{19}$

\footnotetext{
${ }^{15}$ Giles Fletcher, Israel Redux or the Restauration of Israel (London, 1677). See, for example, Thorowgood, Iewes in America (1650), p.39.

${ }^{16}$ Amy Sturgis, "Prophesies and Politics: Millenarians, Rabbis, and the Jewish Indian Theory", Seventeenth Century 14 (1999), 15-23. However, Lee Earnest Huddleston argues that Martyr did not fully espouse the theory (Origins of the American Indians: European Concepts, 1492-1729 [Austin and London: University of Texas Press, 1967], p. 33).

${ }^{17}$ Acosta argued that the Indians were so far from Hebrew ceremonies that they could not be Jews, unless they had experienced a cataclysmic degeneration. Garcia was much more positive, granting the theory a great deal of space and attempting to rebut Acosta's objections. He did not espouse one particular opinion above others, however. On this see Huddleston, Origins, pp. 48-76.

${ }^{18}$ The most that Mede can hope for from the plantations is that the English will not degenerate and make up the hordes of Gog and Magog assaulting the New Jerusalem. This is laid out in a letter to William Twisse of 23 March 1634/5. See Joseph Mede, The Works of the Pious and Profoundly Learned Joseph Mede (London, 1672) pp.798-803. On Torquemada's influence see Cañizares-Esguerra, pp.100-104.

${ }^{19}$ Sturgis focuses on the correspondence sent between the main figures, but claims an over-developed political allegiance between them (see especially, "Prophesies and Politics", p.18). This follows Clare Jowitt's assertion that much of the work on the topic is politically motivated ("Radical Identities?" pp.101-119). 
Although the Jewish Indian theory was occasionally mentioned prior to the 1640 s, most notably in Edward Brerewood's Enquiries touching the diversity of languages and religions (1614), ${ }^{20}$ questions about the location of the lost tribes became more prominent in the 1640s. These discussions were part of a wider public debate about England's American plantations, finding their most important form in a series of letters from New England which began to be published from 1643 . After 1649 these publications became more regular under the authority of the newly formed Corporation for the Propagation of the Gospel in New England (or New England Company). ${ }^{21}$ Each of these tracts generally adopted a set form, beginning with an introductory letter written either by board members or by a New England minister. These tended to highlight the godliness of the planters' work and connect it to the English context, as well as directly pleading for money. The letters which were the main selling point of the collections came from a number of New England ministers. These included Thomas Mayhew Jr. of Martha's Vineyard, John Wilson of Boston and Thomas Shepard of Cambridge. The most regular contributor was John Eliot, the minister at Roxbury known as the "apostle to the Indians". There were several reasons for their publication. The letters served as a way of demonstrating that claims that New England had failed in its duty in sharing the gospel with Indians were false. The tracts also had a much more basic purpose: they aimed to raise money for work among the natives. ${ }^{22}$ Eliot continually complained about

\footnotetext{
${ }^{20}$ A section of Brerewood's work is dedicated to the question of the location of the tribes, and a denial of claims that they were amongst the Tartars, or that the Tartars (and thus tribes) had populated America. See Edward Brerewood, Enquiries touching the diversity of languages and religions through the chiefe parts of the World (London, 1614), pp.92-112.

${ }^{21}$ These are usually referred to, slightly misleadingly, as the "Eliot Tracts". While the majority of the tracts do focus on Eliot, he is far from the only minister whose correspondence is published in them. The tracts have been edited and published together - see Michael P. Clark (ed.), The Eliot Tracts (London: Praeger, 2003).

${ }^{22}$ Kristina Bross, Dry Bones and Indian Sermons: Praying Indians in Colonial America (Ithaca and London: Cornell University Press, 2004), pp.1-27.

8
} 
lack of funds, and the New England Company's formation had been linked to an impressive national collection for Indian evangelisation organised by parliament. ${ }^{23}$

Edward Winslow's The Glorious Progress of the Gospel Amongst the Indians in New England (1649) was the first of the New England tracts to explicitly deal with the Jewish Indian theory. Winslow was a former governor of Plymouth colony, and therefore boasted impressive first-hand knowledge of the situation on the ground in the plantation. Having returned to England as official representative of Massachusetts Bay in 1646, he was highly motivated to promote the benefits of the planters' efforts. Dedicated to parliament, The Glorious Progresse urged further support of evangelisation of the Native Americans. As part of his promotional work, Winslow attempted to deal with the thorny question of the present location of the ten tribes and the identity of the natives of America. ${ }^{24} \mathrm{He}$ used his position as an eyewitness to argue that in his observations of the natives he had seen "some things enjoined in the ceremonial law of Moses". These signs could be cultural, such as the way in which menstruating women were separated from the rest of the tribe, or religious, such as monotheistic belief and global flood stories. ${ }^{25}$ The millenarian minister John Dury wrote a postscript to support Winslow's conjectures on the tribes. Having given consideration to their content, he had been led "to think, that there may be at least a remnant of the generation of Jacob in America (peradventure some of the 10 tribes dispertions [sic]) and that these

\footnotetext{
${ }^{23}$ Linda Gregerson, "The Commonwealth of the Word: New England, Old England, and the Praying Indians" in Linda Gregerson and Susan Juster (eds), Empires of God: Religious Encounters in the Early Modern Atlantic (Philadelphia: University of Pennsylvania Press, 2011), pp.70-83.

${ }^{24}$ Edward Winslow, The Glorious Progress of the Gospel amongst the Indians in New England (London, 1649), sig. A2 ${ }^{\mathrm{i}} \mathrm{r}$.

${ }^{25}$ Winslow, Glorious Progress, sigs. A2 ${ }^{\mathrm{i}} \mathrm{v}-\mathrm{A} 2^{\mathrm{ii}} \mathrm{r}$.

9
} 
sometimes poor, now precious Indians... may be as the first fruits of the glorious harvest of Israels redemption", ${ }^{26}$

In his own writing, Dury echoed Winslow's thoughts on the cultural similarities between Old Testament Jews and Native Americans. On perusing the sources himself, he added a number of new categories to Winslow's list: the Jews engaged in fasting, were fastidious about preserving records of their lineage, and used metaphorical language in a way that resembled the Jewish prophets. ${ }^{27}$ His thoughts were further crystallised when reading Thomas Shepard's promotion of New England in The Clear Sunshine of the Gospel Breaking Forth Upon the Indians in New England (1647). Shepard, who was not a proponent of the theory himself, ${ }^{28}$ had noted that Eliot's first sermon to natives had been on Ezekiel 37:9-10, a text that predicted that the "dry bones" of Israel and Judah would be revived by the wind of the Spirit. ${ }^{29}$ For Shepard, this was seen as little more than a pleasing anecdote on the possibility of Indian tribes converting: "somewhat observable (though the observation bee more cheerful than deepe)". ${ }^{30}$ In what Kristina Bross has described as Dury's "breathless tone" ${ }^{31}$ however, the choice of text assumed greater providential importance: "Why may we

\footnotetext{
${ }^{26}$ John Dury, "Appendix” in Winslow, Glorious Progress, pp.22-23.

${ }^{27}$ Dury, "Appendix" in Winslow, Glorious Progress, pp.22-25.

${ }^{28}$ Kristina Bross, "From London to Nonatum: Mission Literature in the Transatlantic World" in Linda Gregerson and Susan Juster (eds), Empires of God: Religious Encounters in the Early Modern Atlantic (Philadelphia: University of Pennsylvania Press, 2011), p.136.

${ }^{29}$ For Bross this text also serves as the "governing metaphor" of missionary activity, particularly for John Eliot (Bross, Dry Bones, p.41).

${ }^{30}$ Thomas Shepard, The Clear Sunshine of the Gospel Breaking Forth Upon the Indians in New England (London, 1647), p.33. Shepard's reason for relating this story is the coincidence that the Algonquian word for "wind" ("Waubon") was also the name of the converted Native American who was the "most active Indian for stirring up other Indians".

${ }^{31}$ Kristina Bross, "From London to Nonatum", p.129. 
not at least conjecture, that God by a special finger pointed out that text to be first opened, which immediately concerned the persons to whom it was preached?"32

The most important work on the "Jewish Indian" theory also had Dury to thank for its publication. Thomas Thorowgood's 1650 Iewes in America, or Probabilities that the Americans are of that Race was first written in the late 1630s and had been worked on by the Norfolk minister throughout the next decade. Thorowgood's text, as the title suggested, aimed to promote the Jewish Indian theory as a thorough examination of the supposed resemblances between the Americans and the Jews. Like Winslow, Thorowgood traced a range of similarities between the people groups. Thorowgood highlighted linguistic parallels between Indian languages and Hebrew. He remarked upon the seeming monothesism and presence of circumcision, as well as the way in which Indian clothing resembled Old Testament descriptions of Jewish apparel. Even the seeming barbarity of the native peoples could be explained by the fact that cannibalism was one of the curses threatened by God against the Jews in Deuteronomy 28:53 should they break his covenant. ${ }^{33}$ Dury wrote a preface to the book, and it seems likely that it was his encouragement that finally pushed Thorowgood towards publication. ${ }^{34}$ It certainly appears that reading the text in manuscript finally convinced Dury of the likelihood of the Jewish Indian theory. ${ }^{35}$ Where once he had found it "incredible, rediculous and extravagant, strang and unlikely [sic]" the book's exegesis and Dury's own wide ranging knowledge combined to make him a proponent of theory. Thorowgood's text was republished in 1652 as Digitus Dei: New Discoveryes.

\footnotetext{
32 Dury, “Appendix”, in Winslow, Glorious Progress, p.23.

33 Thomas Thorowgood, Iewes in America (1650), pp.1-44.

${ }^{34}$ John Dury, “An Epistolicall Discourse Of Mr. IOHN DURY, TO Mr. THOROWGOOD” in Thorowgood, Iewes in America (1650), sigs. D3v-D ${ }^{1} \mathrm{r}$.

${ }^{35}$ Thorowgood had to remove a dedication to Charles I when events overtook him in 1648 . 11
} 
Whether this was a sign of the work's popularity, or a cunning ruse by the printer to shift remaindered stock is unclear. ${ }^{36}$

Thorowgood's next publication, also entitled Jews in America (1660), was nonetheless a new text. It was primarily a defence of his original publication from criticism it had received in Hamon l'Estrange's 1651 Americans no Iewes. l'Estrange had identified a number of problems in Thorowgood's method. At its roots, this debate recapitulates the earliest dispute surrounding the question of the origin of the Indians between José de Acosta and Gregoria Garcia which turned on the question of whether any comparison could be made between the customs of various people groups: Acosta had seen such comparisons as absurd, while Garcia had defended them. ${ }^{37}$ Taking Acosta's position in the debate, l'Estrange pointed out incorrect assumptions made by Thorowgood (such as his claim that Native Americans were commonly monotheistic) as well as what he saw as spurious points of comparison, particularly those "which [are] drawn from the reason of nature, and necessity, and is common to all, as to dance, laugh and sing in matters of joy, to cry, howle and weep in accidents and objects of heavinesse and sorrow". ${ }^{38}$ To rebut the criticism offered by l'Estrange, Thorowgood returned to the cultural comparisons between Native Americans and Jews, providing a greater number from a wider array of sources in an attempt to counteract the criticism.

\footnotetext{
${ }^{36}$ Sturgis claims a wide popularity for the work (Sturgis, "Prophesies and Politics", pp.19-21); Cogley, however, believes Digitus Dei to be the remainder of the 1650 print run with a new title page to generate interest and sell unsold stock (see Richard W. Cogley, "The Ancestry of the American Indians: Thomas Thorowgood's Iewes in America (1650) and Jews in America (1660)", English Literary Renaissance 35:2 (2005), pp.304-330). Ariel Hessayon also suggests that Thorowgood's work was not popular. See: 'Gold Tried in Fire': The Prophet TheaurauJohn Tany and the English Revolution (Aldershot: Ashgate, 2007), pp.138-150.

37 Huddleston, Origins, pp.60-70.

${ }^{38}$ Hamon l'Estrange, Americans no Iewes, or improbabilities that the Americans are of that race (London, 1651), p.66. 
On one level Thorowgood's interest in the theory is slightly puzzling - he was neither a planter himself, nor was he used, as a Norfolk parish minister, to writing extensively on theological controversies. Aside from his publications on the Jewish Indian theory he served on the Westminster assembly, although he was far from notable in its deliberations. In December 1644 he published a sermon he had preached before the Commons, his only publication not to focus on Jews and Native Americans. ${ }^{39}$ Yet Thorowgood was an active campaigner, financial collector, and avid reader of texts relating to the New World, as well as a regular correspondent of Eliot. Iewes in America's long gestation period not only reveals its author's reluctance to involve himself in controversy, but provides something of a timeline of changes in English religion, along with as an ironic comment on Thorowgood's unfortunate habit of being continually overtaken by events. Initially prepared with a dedication to Charles I, Thorowgood put Iewes in America on ice with the outbreak of hostilities between king and parliament. When he returned to the work in the late 1640 s, he had to quickly rethink his general political position in the aftermath of Pride's Purge and the execution of the king. All of this serves as a reminder that while he examined the question of whether the Jews were secret Indians or not, Thorowgood's work was far from politically neutral. His 1650 publication viewed the English church as having been betrayed by Laud, with hope focused on New England's planters. As the final twilight sparkle of the godly church departing the old world, the Presbyterians who fled to New England were bringing about a glorious new dawn; a sunrise that would discover and convert the lost tribes of Israel and lead to the overthrow of the papal antichrist. Thus his approving quotation of George Herbert's prediction that religion would "passe to the American strand" ${ }^{40}$ Given that this was written at some point prior to

\footnotetext{
${ }^{39}$ Thomas Thorowgood, Moderation Justified, and the Lords being at hand emproved (London, 1645).

${ }^{40}$ Thorowgood, Iewes in America (1650), pp.60-87 
1640, the optimism does not seem misplaced, although the fact that he allowed his pessimistic assessment of English religion to remain in a 1650 publication suggests his unease with the direction England was heading in the aftermath of Charles's execution. When he wrote again in 1660 , changing political circumstances allowed him to restore his initial dedicatory epistle to "the king's most excellent majesty" and tone down his praise of New England's polity. The original 1648 prayer for Charles's restoration, finally printed in this edition, thus became a double reference evidencing Thorowgood's loyalty to his heir. A pointed appeal for Charles II to remember David's mercy and tolerance of his abusive subject Shimei, who described him as a "man of blood" (2 Sam 16:13), had clear political relevance to the forthcoming restoration. ${ }^{41}$ It also allowed Thorowgood to engage in further eschatological speculation, mentioning a letter sent by the Dutch millenarian Petrus Serrarius to John Dury and Henry Jessey which supposedly intimated to the king that "your family should be instrumental to the conversion of the Jews". ${ }^{42}$ This sort of royalist millenarianism appeared in a number of works in the $1660 \mathrm{~s}$, and serves as a reminder that the supposedly radical apocalypticism of the 1650 s was more politically malleable than is often thought. ${ }^{43}$

Perhaps the most important aspect of Thorowgood's work was its publication of a text Portuguese-Dutch rabbi Menasseh ben Israel. Menasseh had been in correspondence with a number of millenarian writers such as Dury and Nathaniel Homes for a number of years, and had attracted interest due to his own eschatological speculation and hopes of settling Jews in England. Dury and Homes wrote to the rabbi seeking answers on the question of the location

\footnotetext{
${ }^{41}$ Thorowgood, Jews in America (166), sigs. *v- *2r.

42 Thorowgood, Jews in America (1660), sig. * $2{ }^{\mathrm{ii}} \mathrm{r}$.

${ }^{43}$ For more on this see Warren Johnston, Revelation Restored: The Apocalypse in Later Seventeenth-Century England (Woodbridge: Boydell, 2011). For an example see Arise Evans, Light for the Jews, or, the means to convert them (London, 1664).
} 
of the tribes. Menasseh responded by providing new evidence of the presence of the Jews in America. Winslow mentioned Menasseh in The Glorious Progress as "a great Dr. of the Jewes" in correspondence with "a Godly minister of this city" (most likely Homes). Menasseh, Winslow reported, thought that the tribes "were certainly transported into America, and that they had infallible tokens of their being there". ${ }^{44}$ This was further confirmed in the rabbi's Spes Israelis, and in a copy of a story he claimed to have heard first hand from Jewish traveller Antonio Montezinos. This was translated into English and included at the end of Thorowgood's Iewes in America (1650). ${ }^{45}$ Montezinos was a Portuguese converso who claimed that he had been introduced by natives to a hidden tribe who spoke Hebrew. He had related the story to a meeting of Sephardi elders in Amsterdam, or Mahamad, in 1644 as a way of repudiating his identity as a "New Christian". ${ }^{46}$ Being led to a distant river, he had met the tribe of Reuben, heard them recite the shema, and in discussion with a native guide learned that they were uniquely powerful and kept themselves unpolluted through total separation from the Indians. Having already destroyed huge numbers of Indians who fought them on their first arrival in America, they looked forward to a time when they would emerge to rule the earth and return to their homeland. ${ }^{47}$ Along with its first publication in Thorowgood, the story was included in Moses Wall's Hope of Israel (1651), a sometimes loose translation of Menasseh's Spes Israelis - which had itself included Menasseh's original interpretation of Montezinos's story to rebut Thorowgood's Christian glosses. ${ }^{48}$ The idea of "hidden Jews" in the midst of America was obviously a different

\footnotetext{
${ }^{44}$ Winslow, Glorious Progress, sig. A2 ${ }^{\mathrm{i}} \mathrm{v}$.

${ }^{45}$ John Dury, "Discourse" in Thorowgood, Iewes in America (1650), sig. e2r. Thorowgood's work was the first to print a translation of Montezinos' report, taken from Menasseh's French copy and translated by Dury. See "The Relation of Master Antonie Monterinos, translated out of the French copie sent by MANASEH BEN ISRAEL" in Thorowgood, Iewes in America (1650), pp.129-139.

${ }^{46}$ Perelis, "Lost Tribes", pp.195-199.

${ }^{47}$ Menasseh ben Israel, "The Relation of Master Antonie Monterinos" in Thorowgood, Iewes in America (1650), p.136.

${ }^{48}$ Perelis, "Lost Tribes", p.199.
} 
position from the notion that the Jews had "become" the Indians through a process of cultural amnesia - for Menasseh they kept themselves radically separated out from the natives. ${ }^{49}$ Although at times Menasseh made use of a similar method of cultural comparison to Thorowgood, he believed that any Hebraic traits among Indians were down to imitation rather than secret Hebrew identity. The lost tribes might be hidden in America, but they certainly were not the Indians of New England. ${ }^{50}$ Nonetheless, by admitting Jewish influence on the natives, Menasseh became a powerful witness in Thorowgood's favour.

\section{The Jewish Indian Theory in Atlantic Context}

Amy Sturgis has noted that the "Jewish Indian" theory could serve as a method of uniting those who held to vastly differing religious positions. ${ }^{51}$ For example, the theory was espoused by Dury, Menasseh, and Thorowgood, and all used it to argue in favour of the readmission of the Jews to England. This does not negate the obvious religious differences between them, but it does show the utility of the theory as a tool through which political ends could be pursued. Works on the tribes were also used as a way to critique contemporary English political events. Recent scholarship has highlighted the way in which the theory could be used to comment upon Cromwell's foreign policy or the political project of the New England plantations. ${ }^{52}$ The English political context is certainly important in this debate, and has been explored in detail by Sturgis. But in the remainder of this chapter I want to explore

\footnotetext{
${ }^{49}$ For more on this see For more on this see Richard H. Popkin, "The Rise and Fall of the Jewish Indian Theory", in Yosef Kaplan, Henry Méchoulan and Richard H. Popkin (eds), Menasseh ben Israel and his World (Leiden: Brill, 1989), pp. 68-71.

50 ben Israel, Hope, p. 25.

${ }^{51}$ Sturgis, "Prophesies and Politics", pp.17-18.

${ }^{52}$ See Jowitt, "Radical Identities".

16
} 
the debates surrounding the theory in a slightly different context - that is, the way in which they involved an Atlantic-wide intellectual community. Michael Hoberman's recent exploration of Jewish themes in New England thought makes exactly this point: ideas such as the Jewish Indian theory could open up new intellectual networks to writers. ${ }^{53}$ But these ideas also developed through the physical movement of settlers. As Carla Gardina Pestana has argued, the Atlantic world was marked by the constant movement of people between the three kingdoms and English plantations overseas. ${ }^{54}$ As individuals and ideas flowed backand-forth either physically, or in what Laura Stephens has described an "epistolary community" through missionary letters, so local political and religious contexts helped to forge wider Atlantic intellectual debates. ${ }^{55}$ The passage to New England did not have to be a one-way journey, as Susan Hardman Moore has memorably shown in her work on those settlers who returned to England, thus helping to foster the sense of inter-connected transatlantic communities. ${ }^{56}$

Although the Jewish Indian theory is generally seen within this British Atlantic framework, it is helpful to expand and develop this by thinking about the wider geographical context in which these theories had been debated. While the role of England in discovering the location of the lost tribes was at the forefront of the English writings on the subject, the major figures in the debate were spread across the whole Atlantic world. Although debates on the theory in English may have placed some of their focus on ethnographic data and the

\footnotetext{
${ }^{53}$ Michael Hoberman, New Israel/New England: Jews and Puritans in Early America (Amherst and Boston: University of Massachusetts Press, 2011), pp.13-17.

${ }^{54}$ Carla Gardina Pestana, Religion and the Making of the British Atlantic World (Philadelphia: University of Pennsylvania Press, 2009), pp.71-77.

${ }^{55}$ Laura M. Stevens, The Poor Indians: British Missionaries, Native Americans and Colonial Sensibility (Philadelphia: University of Pennsylvania, 2004), pp.62-83.

${ }^{56}$ Susan Hardman Moore, Pilgrims: New World Settlers and the Call of Home (New Haven and London: Yale University Press, 2007) and Abandoning America: Life Stories from Early New England (Woodbridge: Boydell, 2013). 
reports of settlers, they also served as a way of debating the interpretation of key texts on natives then circulating within the Atlantic world. This included not just the British Atlantic, but particularly Spanish and Dutch sources as well. Montezinos, whose story caused so much excitement, was after all the archetypal citizen of this new world: "being a Portugal, a Jew of our order...he went to the Indies...I myself was well acquainted with him when he lived here [in Amsterdam]... then he went to Farnambuc [Pernambuco], where two years after he died". ${ }^{57}$ His story was then passed back and forth across the ocean. Firstly this was through correspondence with Dury and Homes in England, who were in contact with Thorowgood. The story was likely also in circulation in the circle surrounding Samuel Hartlib as early as 1649 - it is approvingly, albeit briefly, referenced by John Sadler in his Rights of the Kingdom. ${ }^{58}$ In 1650, John Eliot was writing to Winslow from New England desperate for him to gain more information from Dury:

First, for that of Rabbi-ben-Israel which you mention, I would intreat you to request the same Godly minister [Dury]... to send to him to know the grounds, and how he came to that intelligence, when was it done, which way were they [the tribes] transported into America, by whom, and occasion, and how many... 59

While the "Jewish Indian" theory did not find widespread acceptance in New England, it was nonetheless an idea that was developed through a correspondence network that spanned the Atlantic world. While the debate has often been seen almost exclusively in terms of its English context, it was a product of international correspondence and discussion. While the debate as a whole could be used to reiterate the "black legend" of Spanish barbarity

\footnotetext{
57 ben Israel, Hope, p.35.

${ }^{58}$ John Sadler, Rights of the Kingdom (London, 1649), pp.37-38.

${ }^{59}$ John Eliot in Henry Whitfield, The Light Appearing more and more towards the perfect day, or a further discovery of the present state of the Indians in New England (London, 1650), p.14.
} 
(and English civility) to natives, it would be wrong to view it solely in an English political context. Indeed, as Cañizares-Esguerra has suggested, the idea of Spaniards as satanic conquerors originated in Iberian debates about imperial policy. ${ }^{60}$ Instead, the theory should be examined with reference to the information network which helped support it. Thorowgood, while never having been to New England, therefore gained his information not solely from those working in the colonies, but from Dury's international correspondence and Iberian works on the New World of the sixteenth and early seventeenth century. Menasseh also conducted the debate in terms of similar academic works and correspondences. When he began the second section of Hope with the statement: "You must know, therefore, that Alexis Vanegas saith that the first colonies of the West-Indies were of the Carthiginians", he fully expected his readership to be conversant in both the wider debate and the academic sources that he quoted. ${ }^{61}$ Thorowgood used a number of works including Genebrardus's Chronographia in duos libros distincta (1567), José de Acosta's Historia natural y moral de las Indias (1590), Joannes Lerius's Historia Navigationis in Brasiliam (1586) and Joannes de Laet's Mundo Nuevo (1640). Some of these sources had been translated into English - for example, Acosta's Historia had been published as The Naturall and Morall Histories of the East and West Indies by Edward Grimston in 1604. But mostly Thorowgood seems, as with the majority of the texts he employed, to have used the Latin original. When l'Estrange attacked Thorowgood's work, he made use of the same texts to undermine the claims made in Iews in America (1650). The dispute therefore turned on the way in which these sources were used. While Thorowgood might claim that regular washing showed a cultural affinity between Jews and Americans, l'Estrange responded with a catalogue of Atlantic writers: "Jo. de Laet. Ind. occid. lib.15. cap. 2. saies, the Brasilians...eate their meat illotis manibus, with

\footnotetext{
${ }^{60}$ Cañizares-Esguerra, Puritan Conquistadors, pp.35-82.

${ }^{61}$ ben Israel, Hope, p.17. The writer referred to is the mystic Alejo Venegas de Bustos (1497/8-1562). For Venegas see Huddleston, Origins, pp.20-21.
} 
unwashed hands. And Purchas America cap.5. saies...and whereas Lerius hath a non-nulli that wash before and after meals, this denotes but a few... and Lincschot saies...[and] the Jesuit Sevrarius quotes..." 62 In responding, Thorowgood therefore returned to his own sources, again placing himself squarely within an Atlantic intellectual context. This included fulsome praise for the Jesuit Acosta: "I cannot but commend his zeal for Christ and Christianity".

Alongside Acosta's work, Thorowgood included references to new works that he had consulted since the first edition of his treatise. The most important of these was Garcilasso de la Vega's Le Commentaire Royal, ou l'historie des Yncas, Roys du Peru published in Paris in 1633, which enabled him to establish further connections between Americans and Jews. ${ }^{63}$ At its roots, the debate surrounding the "Jewish Indian" theory was not just about the religious and ethnographic questions that troubled early modern writers, but was equally concerned with the interpretation of the key intellectual texts about the New World then in circulation within in the Atlantic sphere. When John Eliot wrote to Thorowgood about the theory he therefore apologised for his ignorance of the debate: "I have not the help of variety of authors, my only guide is the holy scriptures". ${ }^{64}$ Like many eschatological works of the seventeenth century which appear to be concerned primarily with their own national context, the debate on the "Jewish Indian" theory and the role of natives in the conversion of the Jews must therefore be seen as part of European intellectual tradition. ${ }^{65}$ When the New World became a subject for eschatological speculation, with the "Jewish Indian" theory as a catalyst, this debate expanded into the Atlantic. The abiding irony of this may be, however, that while

\footnotetext{
${ }^{62}$ l'Estrange, Americans no Iewes, pp.18-19.

${ }^{63}$ For more on this work see Cogley, "Ancestry of the American Indians", p.326.

${ }^{64}$ John Eliot in Thorowgood, Jews in America (1660), p.2.

${ }^{65}$ For more on this see Crawford Gribben, Evangelical Millennialism in the Transatlantic World, 1500-2000 (Basingstoke: Palgrave Macmillan, 2011), pp.20-36.
} 
writers around them were making use of their earlier material, Spanish scholarship on Indian origins became increasingly insular over the seventeenth century.

While the debate on the possible Jewish origins of the Native Americans involved Protestants, Catholics, and Jews, it would be wrong to suggest that their findings were used uncritically. The insularity of Spanish scholarship mentioned above applies primarily to the limiting of debates to the Iberian peninsula, but participants in discussions in New and old England and the Netherlands deliberately sought to place careful limits of texts they used from outside of their own traditions. The use of Spanish sources was therefore often surrounded by careful qualifications. In some respects this was a familiar strategy: using the Spanish Dominican Bartolomé de las Casas' works as a way of supporting the "black legend" of Spanish cruelty was an English commonplace. ${ }^{66}$ Spain's supposed barbarity, whether against natives or on its own soil in the Inquisition, became for some an explanation as to why the Indians denied their Jewish roots. Renegade Dominican Thomas Gage, in a letter to Thorowgood on native practices in Mexico, claimed that the notoriety of the Inquisition's practices against Jews had spread to the New World: "These dare not make open shew of Jewish rites, that may seem differing from the gospel, by reason of the Inquisition, curbing all such Jewish practices, yet in private discourses the most ancient of them will talk of things practiced by their forefathers, agreeable to that we read of Israel"'. While probably little more than the expedient of avoiding discussion of indigenous practices in front of Catholic authorities, for Gage this became a pretext for discussing the similarities between Jewish and

\footnotetext{
${ }^{66}$ Carla Gardina Pestana, "Cruelty and Religious Justifciations for Conquest in the Mid-Seventeenth Century English Atlantic" in Linda Gregerson and Susan Juster (eds), Empires of God: Religious Encounters in the Early Modern Atlantic (Philadelphia: University of Pennsylvania Press, 2011), p.37-57 
Indian religious activity in which Spain and Catholicism could be condemned, and the relative silence of the Indians explained. ${ }^{67}$

Another strategy employed when using Catholic sources was to attempt to rehabilitate the authors through providing copious justification for their quotation. Thorowgood thus attempted to support his use of Jesuit material by arguing that Acosta was far less Catholic than he might initially appear. Not only did he refuse to account the Apocrypha as canonical, but he also denied claims of miracles in Catholic conversion and attacked Spanish abuses of natives. Acosta additionally dismissed the possibility of natives possessing "implicit", rather than demonstrating "explicit" faith (an opinion "expresse with the Reformed churches"). ${ }^{68}$ This use of Acosta had two advantages. At one level, this praise of the Jesuit was a useful rhetorical strategy, for it allowed Thorowgood to make use of an important source while ignoring the fact that Acosta dismissed the Jewish Indian theory. Indeed, in praising Acosta's rejection of the Apocrypha and the "implicit" faith of natives, Thorowgood was turning the Jesuit's arguments 180 degrees. Acosta had dismissed the idea of a Jewish translation to America based on the apocryphal book of Esdras as a Hebraic fantasy, while the fact that Indians did not show any implicit belief was used to argue against any latent Judiasm. ${ }^{69}$ By transforming these criticisms of the theory into reasons for praise, Thorowgood was able to make use of Acosta while ignoring his criticism of the theory itself. This leads onto a second reinterpretation of the Jesuit. In Thorowgood's reading Acosta emerged as a Protestant in all but name, suggesting that while the English minister was happy to make use of Catholic sources, he viewed it as expedient to interpret their religious positions through a Protestant filter. Ironically, this was precisely the strategy he employed in his interpretation of Indian

\footnotetext{
${ }^{67}$ Thomas Gage in Thorowgood, Jews in America (1660), pp.35-36.

${ }^{68}$ Thorowgood, Jews in America (1660), pp.21-22.

${ }^{69}$ José de Acosta, The Naturall and Morall Historie of the East and West Indies (London, 1604), pp.74-77. 22
} 
practices, as native beliefs were revealed as partially submerged forms of Judaism. The alien became familiar and the other became understandable in Protestant terms.

As an opponent of the theory l'Estrange used the same strategy, albeit employed in a different direction. Again, this related to the reliability and the types of sources that were being used in the wider Atlantic intellectual sphere. Menasseh was therefore attacked as "a perfect Talmudist and Rabinicall doctour" with readers being directed back to Brerewood to deal with the main substance of the rabbi's arguments. The rabbi was further accused of being scheming in his political use of the Jewish Indian theory to gain political advantage, and of gullibility in choosing to believe Montezinos's tale: "I finde him a man of so sharpe an appetite, and strong and ostrich concoction, as I cannot sit at table any longer with him". ${ }^{70}$ While l'Estrange could not play the same guilt by association card against Thorowgood's use of Catholic sources (as he also employed them), he could cast aspersions on the supposed good motives of New England planters. Where Thorowgood saw New England's planters as in the vanguard of godliness, l'Estrange could only detect double dealing. With one eye on the antinomian controversy, he condemned Massachusetts as a country which produced "monstrous births of opinions". Where an interest in spreading the gospel was proclaimed, "I fear there is ever more of an inordinate desire of enlargement of wealth and dominion". ${ }^{71}$ Having correctly identified that one of l'Estrange's aims was to encourage fund raising for New England, he called the Norfolk minister on the financial aspects of his appeal and what it implied about Massachusetts's ministers.

\footnotetext{
${ }^{70}$ l'Estrange, Americans no Jewes, pp.75-76.

${ }^{71}$ l'Estrange, Americans no Iewes, pp.69-72. 


\section{Conclusion}

Jorge Cañizares-Esguerra notes that the early modern Atlantic was marked by "not only the transnational circulation of ideas" but also by the use of a "common set of tropes" by all those involved in exploration and colonisation. ${ }^{72}$ It is not surprising that these included eschatological ideas, as both early Iberian exploration and later endeavours in New England both encouraged millenarian speculation. In this context the Jewish Indian theory emerged in mid-seventeenth-century England not only as a result of local political concerns, but also as a symptom of a wider debate on the interpretation of the key texts of Atlantic exploration. This debate involved detailed use of Catholic Iberian sources, as well as interaction between Jewish and Christian scholars. The Jewish Indian theory should therefore be seen in the wider Atlantic contexts of eschatological debates.

This means that when we consider the development of English and North American eschatology, as well as focusing on the way in which it evolved in these parts of the English Atlantic, that we are also aware of the wider Catholic influence. Yet being aware of this wider Atlantic context should not mean that we ignore the local political contexts that motivated the publication of these texts. Questions on the background of religious controversies in the early modern Atlantic cannot be answered by reference to a simple either/or formula: the international and the local both combined to generate texts which engage in wide-ranging debate while having relevance to the particular local circumstances of their composition. Works on the Jewish Indian theory suggest the extent to which controversial disputes, which were often politically motivated by local circustances, could equally be parts of larger debates in wide scholarly networks. This does not mean that we

\footnotetext{
${ }^{72}$ Cañizares-Esguerra, Puritan Conquistadors, p.82.
}

24 
should ignore the political contexts which certainly motivated these debates, but it does mean that we should be aware of a much wider intellectual tradition informing some millenarian ideas in the early modern world. To use David Armitage's terms, this is to advocate an approach which is "circum-Atlantic" in its appreciation of the circulation of ideas which impact upon religious beliefs, but "cis-Atlantic" in that the reception of these ideas is interpreted in local settings with reference to the wider Atlantic context. ${ }^{73}$ A fuller comparison between English and Spanish apocalyptic speculation, particularly in terms of links between early Franciscan ideas of the eschatological importance of the conversion of Native Americans and developing Jesuit commentary traditions, would offer a fruitful way of exploring the complexities of early modern apocalypticism as it developed in England and the Netherlands, and perhaps enable scholars to talk about an "Atlantic eschatology".

\footnotetext{
${ }^{73}$ David Armitage, “Three Concepts of Atlantic History” in David Armitage and Michael J. Braddick (eds), The British Atlantic World, 1500-1800 (Basingstoke: Palgrave, 2002), pp.11-27.
} 